\title{
Strengthening Strategy of Old Bridge in Indonesia (Tukad Yeh Bakung) by Using Optimization and Preservation Approach
}

\author{
I Nyoman Sutarja, I Gede Adi Susila, Made Ari Ariarsha Sumekar \\ Department of Civil Engineering, Faculty of Engineering, Udayana University, Denpasar, Indonesia \\ Email address: \\ nsutarja@unud.ac.id (I N. Sutarja)
}

\section{To cite this article:}

I Nyoman Sutarja, I Gede Adi Susila, Made Ari Ariarsha Sumekar. Strengthening Strategy of Old Bridge in Indonesia (Tukad Yeh Bakung) by Using Optimization and Preservation Approach. Journal of Civil, Construction and Environmental Engineering. Vol. 6, No. 2, 2021 , pp. 46-53. doi: $10.11648 /$ j.jccee.20210602.13

Received: February 9, 2021; Accepted: March 8, 2021; Published: March 26, 2021

\begin{abstract}
A reliable, integrated and sustainable highway road network system throughout the national territory needs to include an upgraded structural capacity of bridges; particularly Tukad Yeh Bakung bridge in Bali-Indonesia. It was essentially needed to improve transportation services to provide direct impacts of economic growth and social welfare locally. To upgrade structural capacity an old bridge has been done by applying a preservation method sustainably: maintenance and rehabilitation in order to keep the bridges provide services properly. This preservation method has also been intended to provide an acceptance and functional criteria (certification of life services) of bridge 50 up to 100 year, and further. An old bridge (Tukad Yeh Bakung) was built in 1977 located along the national road network between Denpasar and Gilimanuk with reference (stationing of km $54+400)$. The bridge was suffered with structural damages due to exceeded load services, earthquakes, and material degradation. The damages of bent was essentially needed to be preserved since the damages found such as cracked and porous on concrete deck/slab and exposed of slab/bending reinforcement which clearly hazard from corrosions as well as decreasing its capacity. Simple bridge preservation has been done by giving additional or replacement of flexural reinforcement as well as a confinement method for the concrete column. Ultimate capacity ratio $(\mathrm{Mu} / \varphi \mathrm{Mn})$ of bent has been evaluated and typical confinement method will also increase lateral load capacity of the pier and prevents of collapse (due to local and global/longitudinal buckling).
\end{abstract}

Keywords: Old Bridge, Preservation, Reliability, Strengthening Method

\section{Introduction}

Problems of this old bridge found to be interesting since the bridge located in Indonesian geology circumstance with high intensity of natural disasters event. The increasing of population and urban movement between district to district and beyond consideration provides degradation of bridge capacity due to old material structures has used and seismic event consists to make the bridge vulnerable. Material structure has been used: reinforcement concrete girder and typical low strength of reinforced concrete frames/pier. To improve the performance of bridge in Indonesia will be reduced vulnerability of structure and to improve performance level of existing bridge means improvement record (passing grade of each bridge record) is essentially needed to be known.
The Tukad Yeh Bakung Bridge needs to be preserved, with several reasons such as: a) The 40-year-old Tukad Yeh Bakung Bridge (built in 1977), b) Visually, the Yeh Bakung Tukad bridge experienced some damage, especially bridge pillars such as cracks and porous concrete decking so that the bend and reinforcement strength is visible, Figure 2. c) change in the rules (code) of bridge loading, especially due to earthquake loads, fulfillment of functional feasibility requirements that have an impact on the necessity for preservation of bridge structures. d) After a 3D Elementary Analysis was carried out, the Tukad Yeh Bakung bridge structure system resulted in preservation.

The capacity of the Tukad Yeh Bakung bridge structure that has been built needs to be intensified routinely for the realization of a reliable, integrated and sustainable road network system throughout the national territory to support 
economic growth and social welfare. Capacity building is done by preservation (maintenance and rehabilitation) to keep the bridge functional during the 50 year plan life. This preservation aims to maintain the Condition of the bridge over the life of the 50 year plan as Figure 1 .

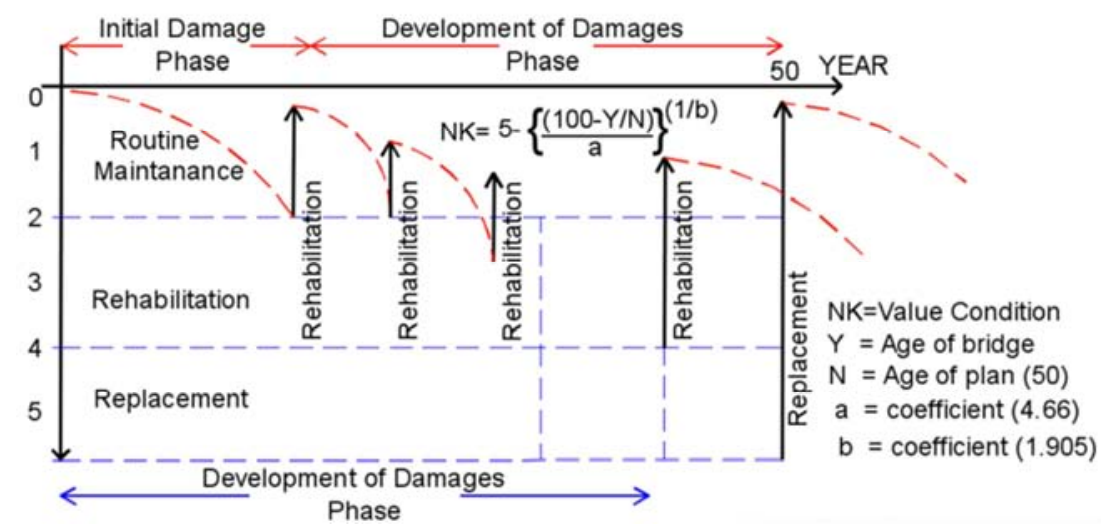

Figure 1. Stages of Preservation During the Age of the 50 Year Plan.

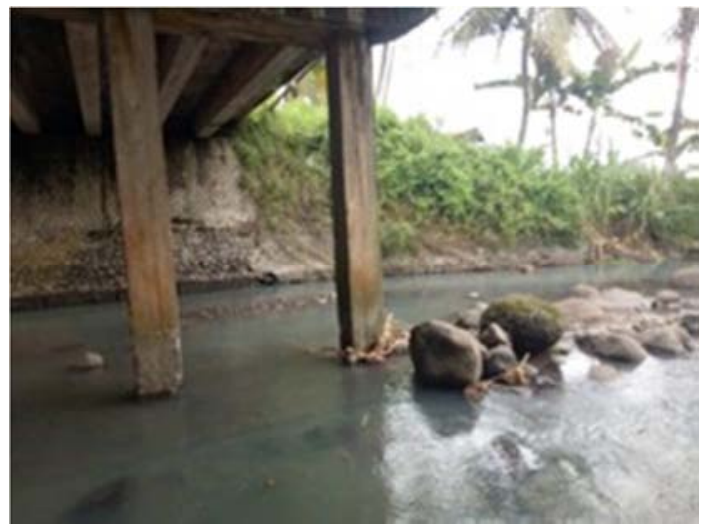

Figure 2. Damage to the Pier of the Tukad Yeh Bakung Bridge.

To find results of improvement and reinforcement and achieve the set targets, it is necessary to conduct an investigation to obtain damage data either through visual observation or with the help of non-destructive or semi-destructive testing and reviewing documents from existing structures. From the results of the investigation, an analysis and evaluation of the structure was carried out to determine whether the damage was only needed to be repaired or needed to be reinforced or in the worst condition the damaged structure must be demolished and new structures constructed. Some progress relates strengthening column/pillar has been developed by using fiber reinforced polymers (FRP) for several loading scenarios including impact load [1]. It necessarily expected to increas the shear capacity and the flexural ductility of reinforced concrete (RC) columns, as in $[2,5]$

In this paper, the preservation discussion is only limited to the column or bridge pillar. The Yeh Bakung Tukad Bridge consists of three regular reinforced concrete beams with buildings under two abutments and two pillar groups such as Figure 3. To confirm new code SNI 1725:2016, survey to identify weaknesses of structural element which was reduce structural performance. Review the bridge structure under extreme dynamic loadings \& structural performance.

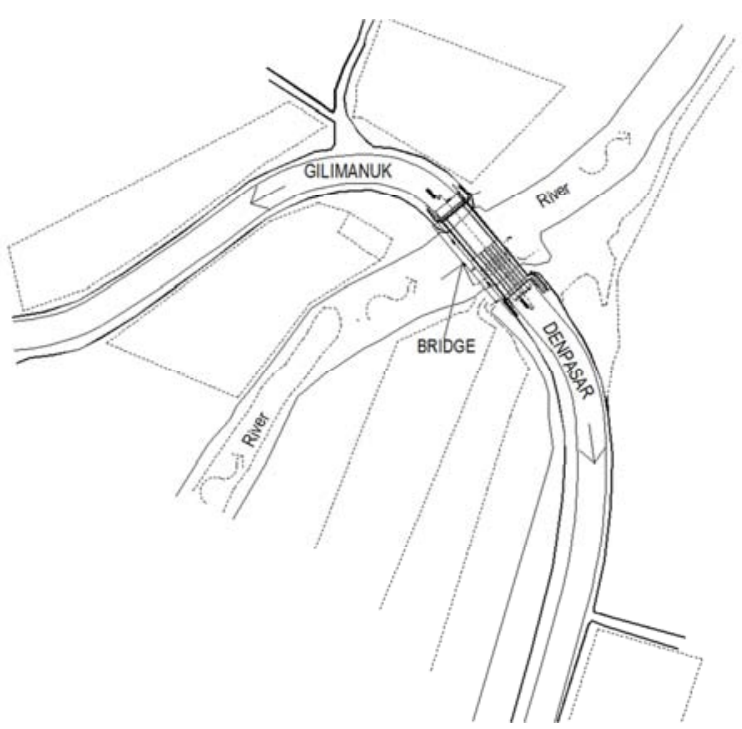

(a)
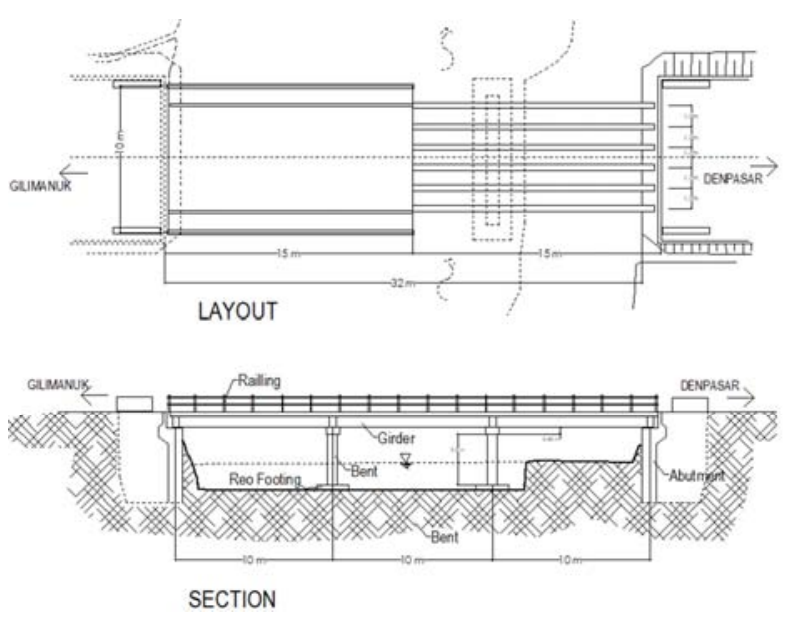

(b)

Figure 3. Typical bridge structure in the as-built existing condition.

Suitable additional structural component to be considered to provide improvement such as bracing, additional composite 
material, additional device (bearing elastomer, energy dissipation unit (EDU)), etc. Analyze any attempt to improve the performance to find the best solution and relatively cheap by numerical analysis. Strengthening Method by using Concrete Jacketing strategy to confirm the Flexural Capacity of Girder and the Bent. Review Structural geometric and possible strengthening Geometric Non-Linearity has been done in order to provide modelling strategy within the FEM simulation in order to meet the standard design.

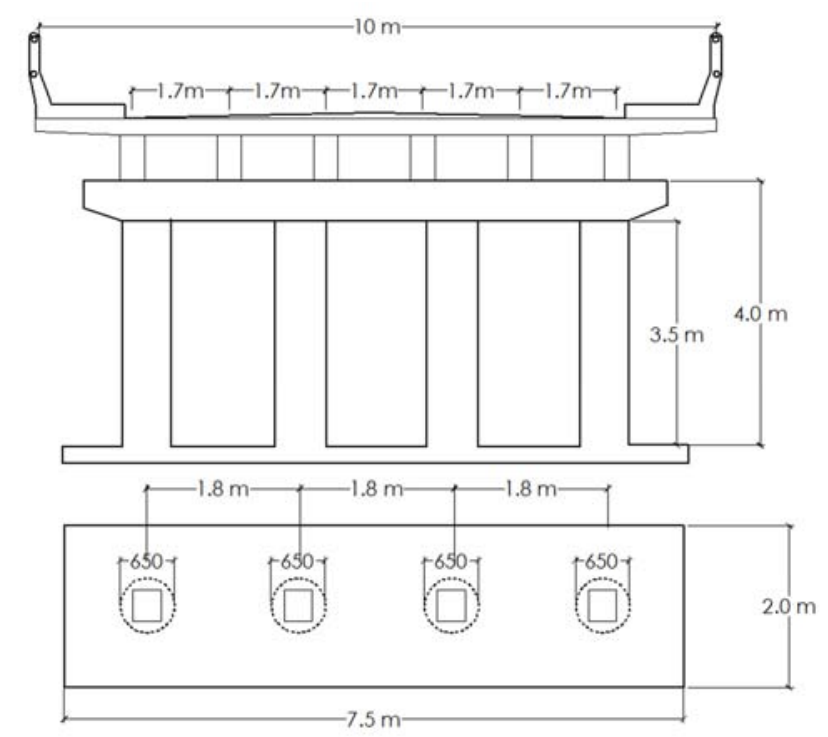

Figure 4. Typical section of pier structure design with RC jacketing using FEM simulation.

\section{Method: Numerical Study (FEM)}

\subsection{Reinforcement Concrete (RC) Jacketing to Strengthen the Existing Pier}

At least, there are two particular purpose of jacketing of pier. (a) To provide shear capacity of pillar relates to strong column-weak beam design, (b) To improve the pier's flexural strength. In order to increase ductility of the bridge structure, all the column/pillar members require strengthening strategy. Therefore, retrofitting of these piers was carried out using RC jacketing.

\subsection{Material}

It has been found that concrete strength of existing bridge to be set to confirm previous test for the existing pier and girders. The concrete strength has been taken to confirm a laboratory test of $\left(f^{\prime}{ }_{c}=21 \mathrm{MPa}\right)$, or K-250, and yield strength of steel reinforcement bar to be set of $(f y=240 \mathrm{MPa})$ for diameter bar less than $13 \mathrm{~mm}$, and $f y$ has been taken of $320 \mathrm{MPa}$ for a diameter larger or equal to $13 \mathrm{~mm}$. These are all material property taken within FEM simulation (CSI Bridge)

\subsection{Bridge Loading}

The loading has been taken from the code of Bridge
Management System (BMS) [6] Code, with revision, SNI-T-02-205 SK, Minister of Public Works Decree No. 498 / KPTS / M / 2005 and Loading for Bridges in 2016 (SNI 1725-2016) [7], based on AASHTO LRFD Bridge Design Specification [8] and the seismic loading code using RSNI 2 Bridge 2833: 201X [9].

$3 \mathrm{D}$ model used to provide analysis by using the FEM package to determine $\varphi M n$ (flexural capacity) under ultimate load $(M u)$ to deal with its ratio. In this study, we discussed arrangement of pier geometry as well as the necessity of reinforcement proposed, where three model namely Pillar-0 as the original one measured of $400 \mathrm{~mm} \times 400 \mathrm{~mm}$. The initial geometry of pier $(400 \times 400 \mathrm{~mm})$ has been strengthened and reinforced with dimension of $550 \mathrm{~mm}$ x $550 \mathrm{~mm}$ as Pillar 1 , and the last alternative is a reinforced geometrically as a rounded one with diameter of $650 \mathrm{~mm}$ as a Pillar 2 .

Ultimate axial load capacity $\left(P_{u}\right)$ of RC column jacketing was calculated under several standard design available. One of clear definition for RC column jacketing can be found in Indian Standard (Is 15988:2013) [5] which is using reduction properly for concrete as well as the reinforcement bar part as follow:

$$
\mathrm{Pu}=0.4 \mathrm{fc} \mathrm{Ac}^{\prime}+0.67 \mathrm{fyAs}
$$

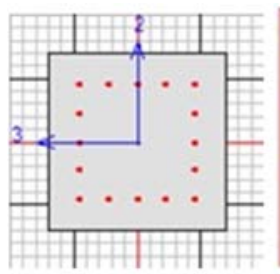

(a)

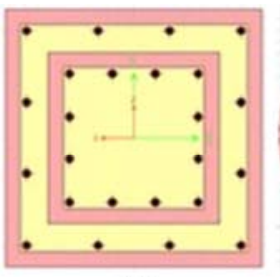

(b)

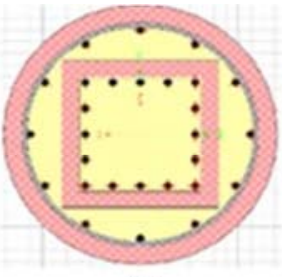

(c)
Figure 5. (a) Pillar 0: existing pier profile, (b) Pillar 1: square, and (c) Pillar 2: rounded jacketing.

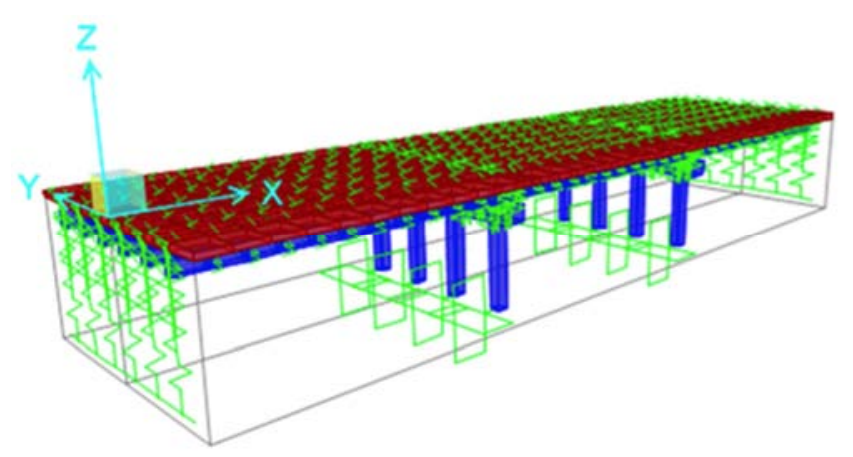

Figure 6. FEM Analysis using CSI Bridges.

Pushover Analysis Static analysis of pushovers is a static nonlinear analysis where the effect of the Earthquake acting on the structure is considered as a static load that occurs at the center of the mass of the structure, whose value is gradually increased until it exceeds the loading which causes the first yield (plastic joint) of structural component, then with further increase in load undergo a large post-elastic shape change until it reaches the expected intermediate target or until it reaches the plastic condition to failure. 


\section{Results and Discussion (Under Pushover Analysis)}

\subsection{Displacement Ratio}

Pushover analysis found that the greatest deflection occurred due to a combination of extreme loads 1 [1], in which Pillar-0 deflected $6.94 \mathrm{~mm}$, for pillars with Pillar-1 reinforcement are $2.64 \mathrm{~mm}$ and Pillar-2 models are $1.55 \mathrm{~mm}$.

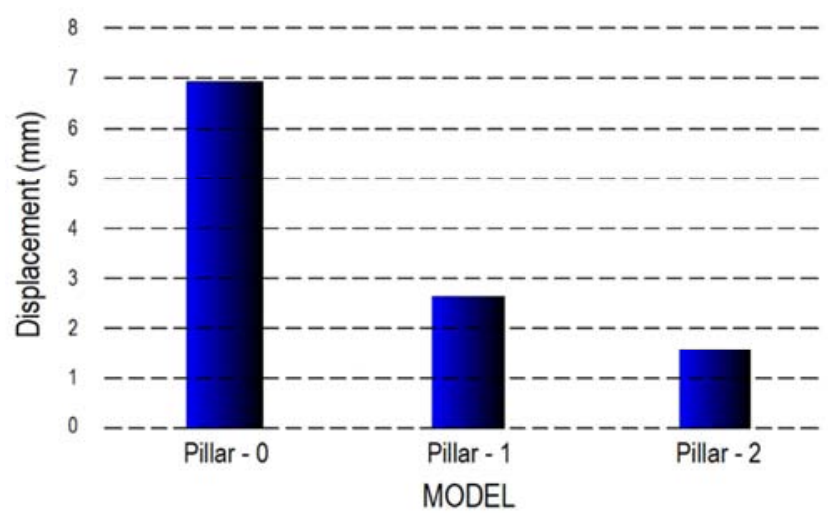

Figure 7. Top drift/displacement of each pillar.

\subsection{Ultimate Capacity Ratio}

The results of the analysis show that the preservation method was carried out by providing reinforcement, confinement from the concrete. Confinement can reduce the ultimate capacity ratio $(\mathrm{Mu} / \varphi \mathrm{Mn})$. The ultimate capacity ratio for the Pillar-0 model is 1.502 , Pillar-1 is 0.679 and Pillar-2 is 0.417 .

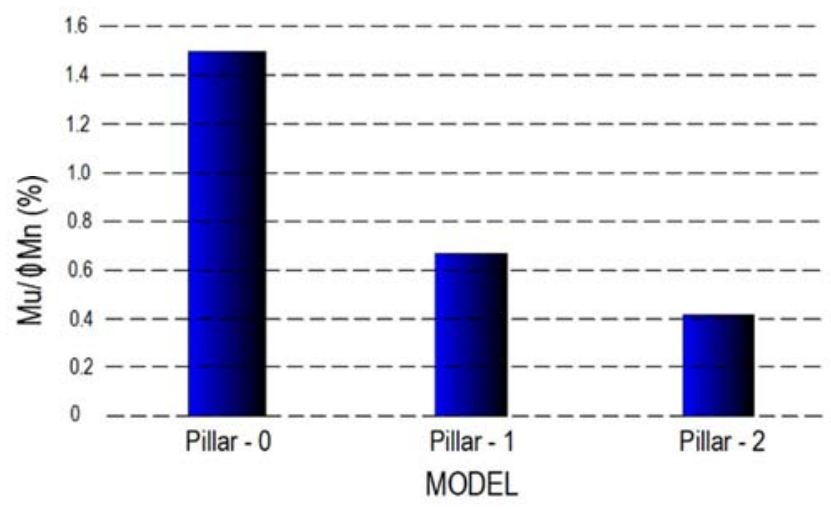

Figure 8. Ulimate capacity ratio found for Pillar: 0, 1, and 2.

\subsection{Maximum Stresses of the Bent/Pillar/Pier}

Based on the results of stress analysis, the maximum stress occurs due to a combination of extreme load 1 where Pillar- 0 without reinforcement is obtained with a maximum stress of 14.38 MPa, followed by Pillar-1 of $6.578 \mathrm{MPa}$ and Pillar- 2 of 3,659 MPa.

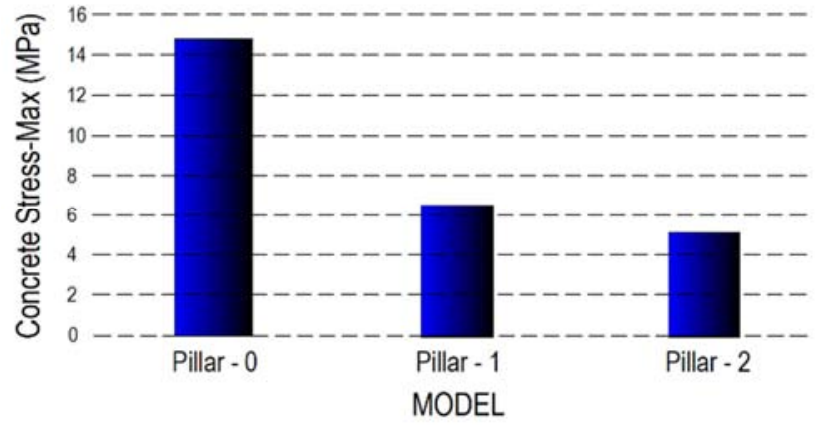

Figure 9. Maximum Stresses occurred for the Pillar: 0, 1, and 2.

\subsection{Structural Performance Level}

Based on the results of the performance point analysis, it obtained the magnitude of the target displacement for the transverse direction of the bridge $(\mathrm{X})$ is $0.059 \mathrm{~m}$. Actual Seismic Response Modification Factor [R] value obtained was 3.8817 and displacement ductility was obtained for 2.3348 . For Demand/Capacity Ratio (DC Ratio) is obtained as in the following: Table 1.

Table 1 shows that Demand-Capacity (D/C) Ratio taken from the pushover analysis found the longitudinal direction of the DC Ratio bridge exceeds the value of 1 . This mean that the lateral capacity of pier less than the demand (external force) such as earthquake and kind of dynamic lateral load to be forced into the bridge. The pier was indicated to be fail and to provide a vulnerable bridge structure for any exceeded lateral load coming. Therefore, strengthening is needed in order to avoid total failure on the structure.

Based on the results of the pushover analysis on the pillars of the Tukad Yeh Bakung bridge without reinforcement the first plastic joint occurred on step 11. In step 23, the performance level of the Life Safety (LS) structure was achieved and the condition of Collapse Prevention (CP) occurred on one of the pillars. Life Safety is the condition of the structure is still in a state able to withstand earthquake loads with little structural damage and users of the structure are still protected from earthquakes. While Collapse Prevention is a condition where the structure has suffered severe damage due to the earthquake, but has not collapsed. It clear that Pillar 0 will provide failure for further the next Earthquake coming.

Table 1. Demand and capacity ratio for pillar 0.

\begin{tabular}{llllll}
\hline SD Category & Span & Station m & Direction & Demand m & Capacity m \\
\hline D & Span 1 & 11.3 & TRANS & 0.0218 & 0.0489 \\
D & Span 1 & 11.3 & LONG & 0.0892 & 0.0554 \\
D & Span 2 & 22.3 & TRANS & 0.0216 & 1.6083 \\
D & Span 2 & 22.3 & LONG & 0.0893 & 0.0489 \\
\hline
\end{tabular}




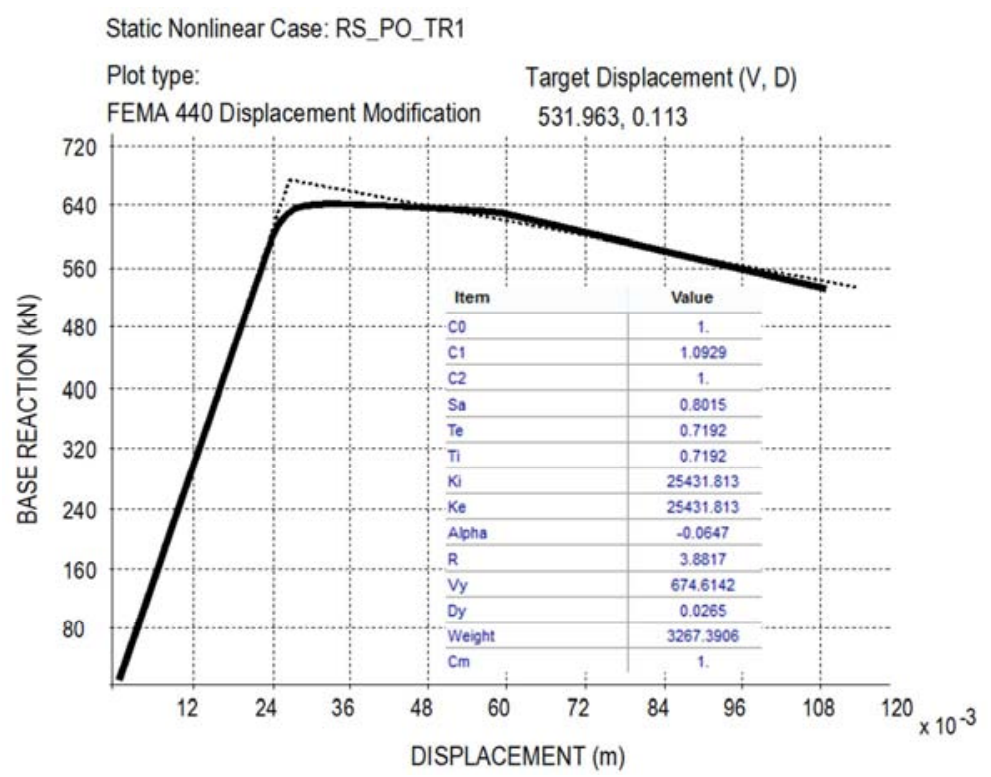

(a)

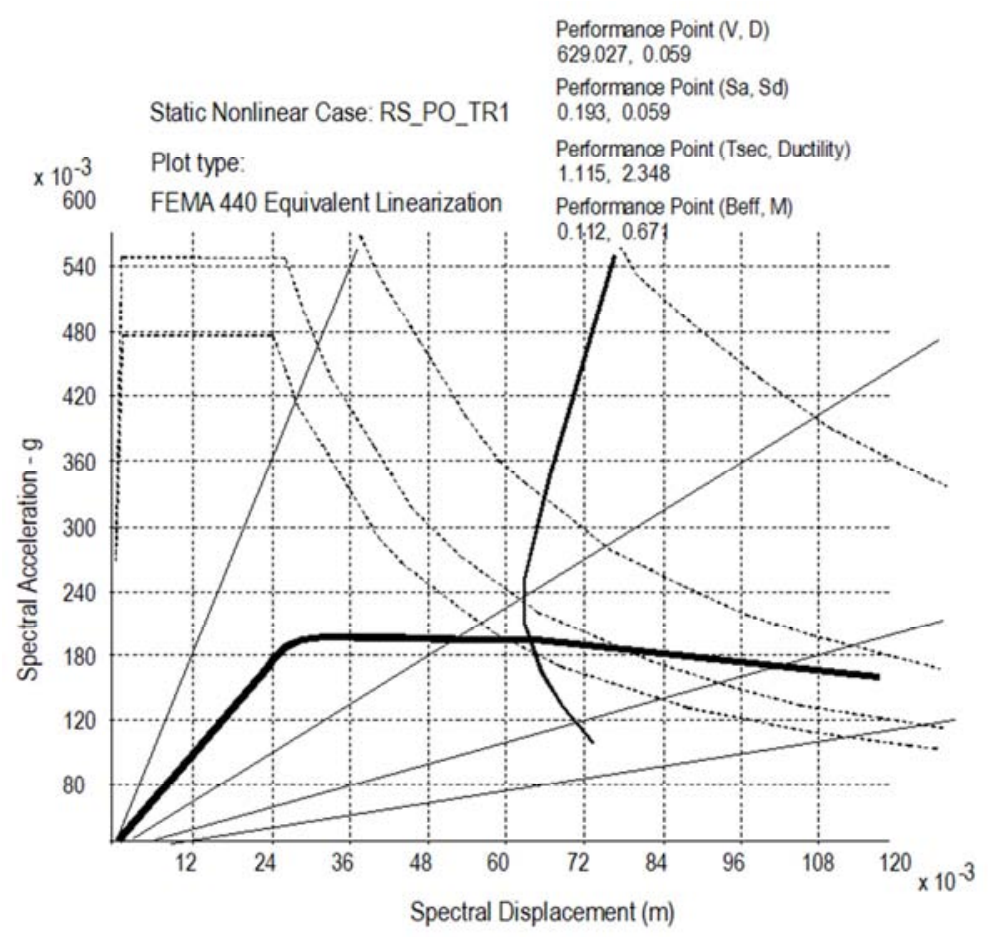

(b)

Figure 10. (a) Reaction base-displacement, and (b) performance point based on FEMA 440 for Pier 0.

Table 2. Demand and capacity ratio for pillar 1 .

\begin{tabular}{lllllll}
\hline SD Category & Span & Station $\mathbf{m}$ & Direction & Demand $\mathbf{m}$ & Capacity m & DC Ratio \\
\hline D & Span 1 & 11.3 & TRANS & 0.0051 & 0.0714 & 0.072 \\
D & Span 1 & 11.3 & LONG & 0.0147 & 0.0586 & 0.250 \\
D & Span 2 & 22.3 & TRANS & 0.0054 & 0.0715 & 0.074 \\
D & Span 2 & 22.3 & LONG & 0.0146 & 0.0586 & 0.250 \\
\hline
\end{tabular}

From the results of the pushover analysis on the Yeh Bakung Tukad bridge pillar 1 reinforcement, the first plastic joint occurs at step 7. In step 34, the Life Safety (LS) structure has been achieved. From pushover analysis on pillar type 2, the reinforcement was taken as the first plastic joint which occurs on step 11. In step 35, it has reached the performance level of Life Safety (LS) structure. The displacement target for bridge crossing $(\mathrm{X})$ is $0.031 \mathrm{~m}$. Actual $\mathrm{R}$ value obtained is 
1.9435 and displacement ductility is obtained at 1.649 . While

in Table 3.

for Demand / Capacity Ratio (DC Ratio) is obtained as shown

Table 3. Demand and capacity ratio for pillar 2 .

\begin{tabular}{lllllll}
\hline SD Category & Span & Station $\mathbf{m}$ & Direction & Demand $\mathbf{m}$ & Capacity $\mathbf{m}$ & DC Ratio \\
\hline D & Span 1 & 11.3 & TRANS & 0.0091 & 0.0583 & 0.156 \\
D & Span 1 & 11.3 & LONG & 0.0294 & 0.0500 & 0.587 \\
D & Span 2 & 22.3 & TRANS & 0.0093 & 0.0583 & 0.159 \\
D & Span 2 & 22.3 & LONG & 0.0294 & 0.0503 & 0.585 \\
\hline
\end{tabular}

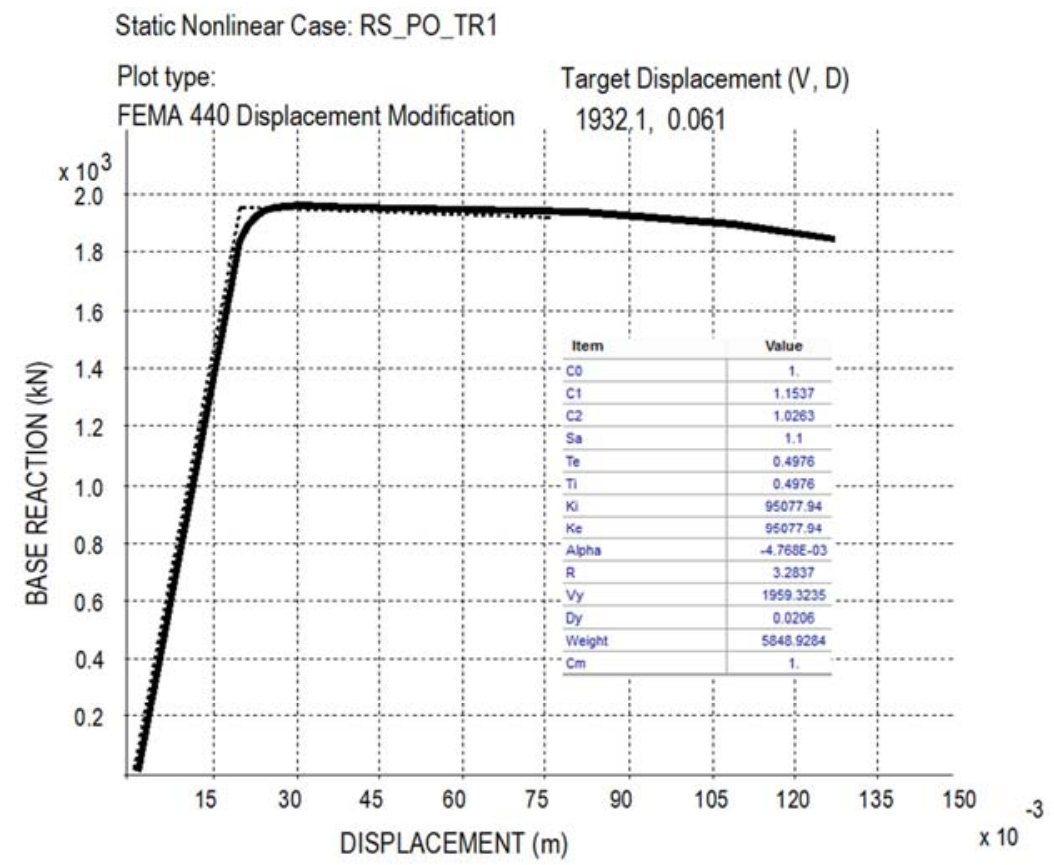

(a)

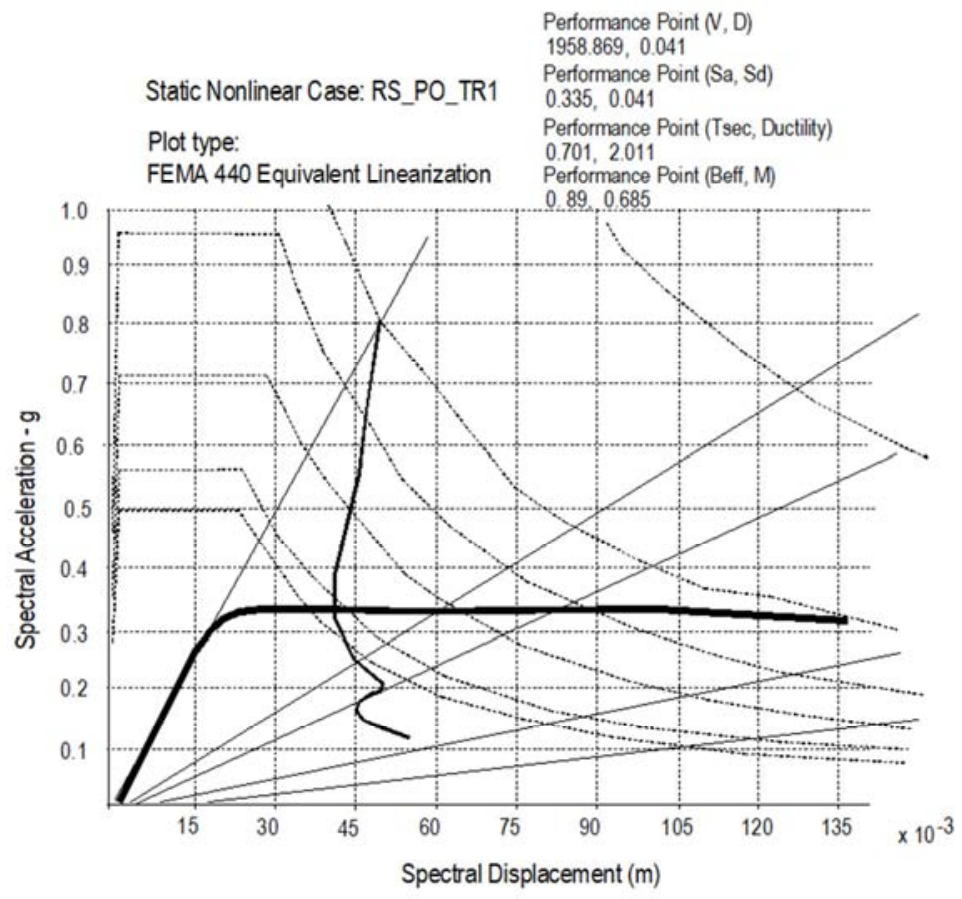

(b)

Figure 11. Reaction base-displacement, and (b) performance point based on FEMA 440 for Pier 1. 


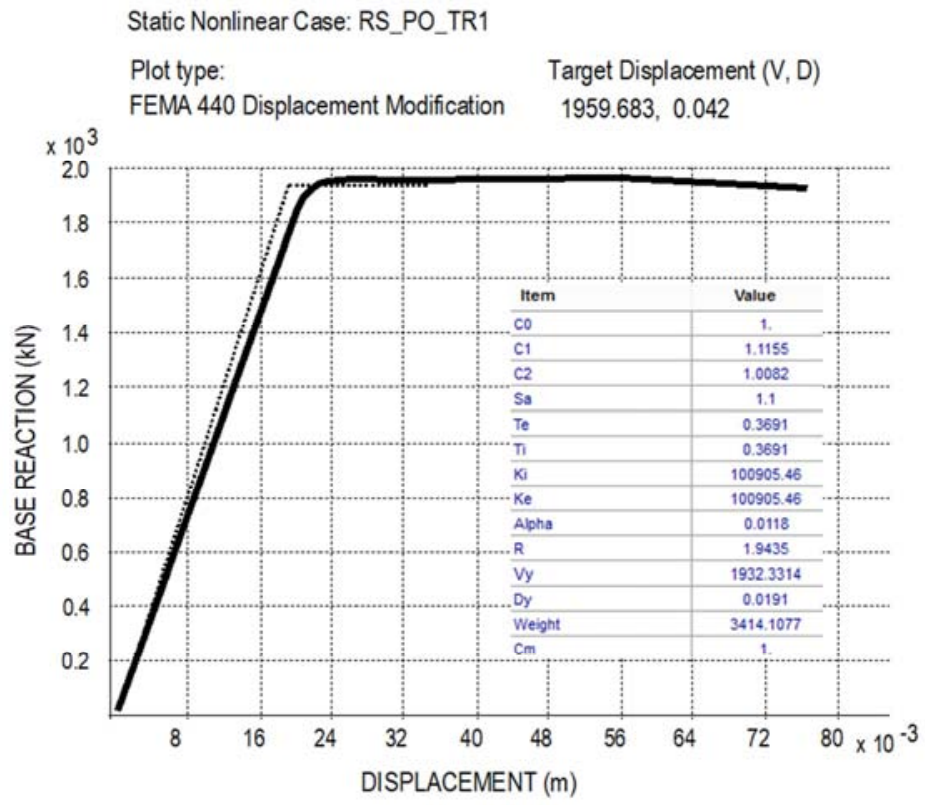

(a)

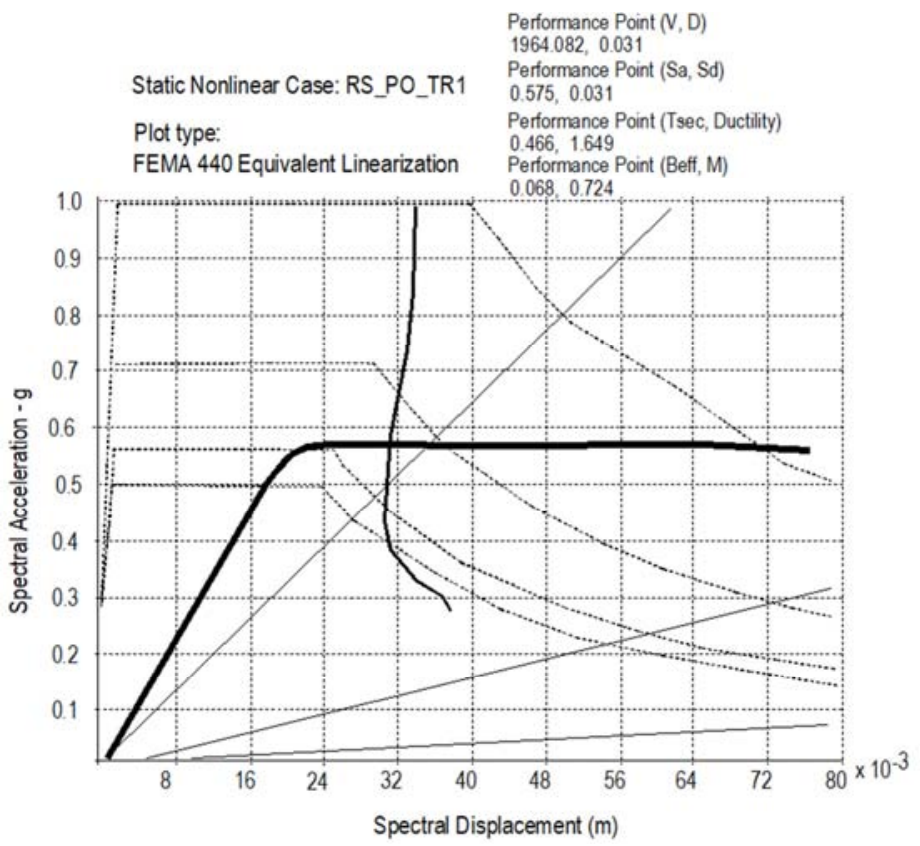

(b)

Figure 12. (a) Reaction base-displacement, and (b) performance point based on FEMA 440 for Pier 2.

The ultimate capacity ratio for existing pillars (Pillar- 0 model) of 1.502 , greater than 1 , so that repairs and reinforcement was needed essentially. The pier with DC ratio more than 1 can be suspected to collapse in near future when the earthquake come and it needed to be retrofitted. Strengthening strategy may taken to design typical as monolithic elements in which contact friction between the old and new concreting provide control of a sufficient slip contact conditions and performance of the strengthened elements considered as "composite" elements, where stated in $[4,5,10-12]$. Hence, strengthening under typical composite profile for the pier, it has been found that $\mathrm{D} / \mathrm{C}$ of Pillar 1 and 2 less than 1 (maximum of 0.58 in longitudinal direction). This means that all strengthening strategy using RC jacketing provides reliable ductility as well as increasing lateral capacity of the pier.

Jacketing procedure has been recognized to some extent to cover possible mechanisms to transfer of shear stresses acting at the interface such as adhesion, friction (including clamping action), steel connectors and bent down bars, which referred in $[3,4,11,13,14]$. However, in this paper, most of study taken to be based on the lateral load capacity of pier which can be determined to evaluate the capacity of a strengthened element as well as the performance level of structures, as may the optimum requirement can be included. 


\section{Conclusion}

The ultimate capacity ratio for the existing pillar (Pillar-0 model) is 1.502 , greater than 1 , so that the repair and strengthening was needed. All strengthening strategies were meet the requirement for the performance level which the maximum level is life safety. FEM Analysis to provide reliable and convenience performance for complicated structures to provide better performance

The numerical works has also been used to estimate lateral carrying load capacity of typical bridges structure under earthquake load or typically pushover analysis (load-displacement control). Elaboration of existing data and some experimental works may be appreciated to confirm the FEM simulation has done. It is important validation of the work in the future with some experimental result to comply reliable applications and extensions study.

\section{Acknowledgements}

Praise God Almighty ('Ida Sanghyang Widhi Wasa'), for the award so that this paper can be completed. Thank you to the Ministry of PUPR, for allowing me to retrieve data on the Tukad Bakung Bridge, and thank to all colleagues who have helped complete this paper.

\section{References}

[1] D. B. Azadeh Parvin, "FRP Composites Strengthening of Concrete Columns under Various Loading Conditions," Polymers, vol. 6, pp. 1040-1056, 2014.

[2] M. R. A. A. B. M. Amrul Kaisha, M. Jamilc, M. A. Wahed, "Ferrocement Jacketing for Restrengthening of Square Reinforced Concrete Column under Concentric Compressive Load," Procedia Engineering (The 2nd International Conference on Rehabilitation and Maintenance in Civil Engineering), vol. 54, pp. 720-728, 2013.

[3] J. B. D. Chris P. Pantelides, Lawrence D. Reaveley,, "Seismic Strengthening of Reinforced-Concrete Multicolumn Bridge Piers," Earthquake Engineering Research Institute, vol. 23, pp. 635-664., 2007.

[4] S. E. D. Konstantinos G. Vandoros, "Concrete jacket construction detail effectiveness when strengthening RC columns," Construction and Building Materials, vol. 22, pp. 264-276, 2008.

[5] P. D. Nikita Gupta, Anil Dhiman, "Design and Detailing of RC Jacketting for Concrete Columns," IOSR Journal of Mechanical and Civil Engineering (IOSR-JMCE), pp. 54-58, 2015.

[6] M. o. P. W. R. o. Indonesia, "Bridge-Design-Manual Volume 1 and 2," ed. Jakarta: BMS (Bridge Management System), 1992.
[7] SNI. 1725:2016, "Standar Nasional Indonesia Pembebanan untuk jembatan. (Indonesian Standard for Loading of Bridges)," ed. Jakarta: BSN (Badan Standardisasi Nasional), 2016.

[8] AASTHO, "AASHTO LRFD Bridge Design Specifications, 6th Edition, with June 2012 Errat," ed. Washington DC, 2012.

[9] RSNI-2833:201X, "Bridge design for earthquake loads," ed: BSN (Badan Standardisasi Nasional), 2013.

[10] S. E. Dritsos, "SEISMIC STRENGTHENING OF COLUMNS BY ADDING NEW CONCRETE," BULLETIN OF THE NEW ZEALAND SOCIETY FOR EARTHQUAKE ENGINEERING, vol. 40, pp. 49-66, 2007.

[11] Y. C. O. G. C. Lee, Z. Liang, T. C. Niu, J. W. Song, "Principles and Performance of Roller Seismic Isolation Bearings for Highway Bridges," MCEER (Earthquake Engineering to Extreme Events2007.

[12] U. V. D. Sachin S. Ravala, "Effectiveness of Various Methods of Jacketing for RC Beams," rocedia Engineering: Chemical, Civil and Mechanical Tracks of the 3rd Nirma University International Conference on Engineering (NUiCONE 2012), 2012.

[13] I. L. K. Reid, Concrete Bridge Strengthening and Repair. London: Thomas Telford, 2009.

[14] T.-W. C. Shuenn-Yih Chang, Ngoc-Cuong Tran, Wen-I Liao, "Seismic retrofi tting of RC columns with RC jackets and wing walls with different structural details," EARTHQUAKE ENGINEERING AND ENGINEERING VIBRATION, vol. 13, pp. 279-292, 1014.

\section{Biography}

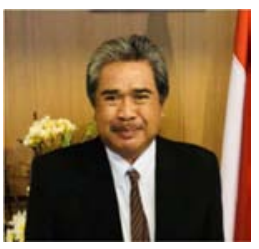

I Nyoman Sutarja, was born in Selemadeg, Tabanan, Bali, Indonesia on March 5, 1958. A Structural Engineering Master's Degree obtained in Civil Engineering Department at the Bandung Institut of Technogy (ITB), Bandung, Indonesia. He was completed Doctoral Program at Udayana University in Denpasar, Bali, Indonesia with concentration in the Ergonomics. His research interests are in the field of increasing serviceability of building structures and bridges for increased safety and reliability. His publication such as The Post-disaster House: Simple Instant House using Lightweight Steel Structure, Bracing, and Local Wood Wall, International Journal of Engineering, Volume \& Issue: Volume 34, Issue 2, TRANSACTIONS B: Applications, February 2021, Pages 305-584 (Dr. Sutarja) As the Bridge and Road Tunnel Safety Commission, Ministry of Public Works and Public Housing of the Republic of Indonesia (SK No. 1003/KPTS/M/2019). He also joint an association membership such as: Indonesian Road Planning Association, Certified as Master Bridge Engineering Expert. 